\title{
Fatigable ptosis as an initial presentation of adult-onset Leigh syndrome
}

Figure Photographs and brain MRI of the patient
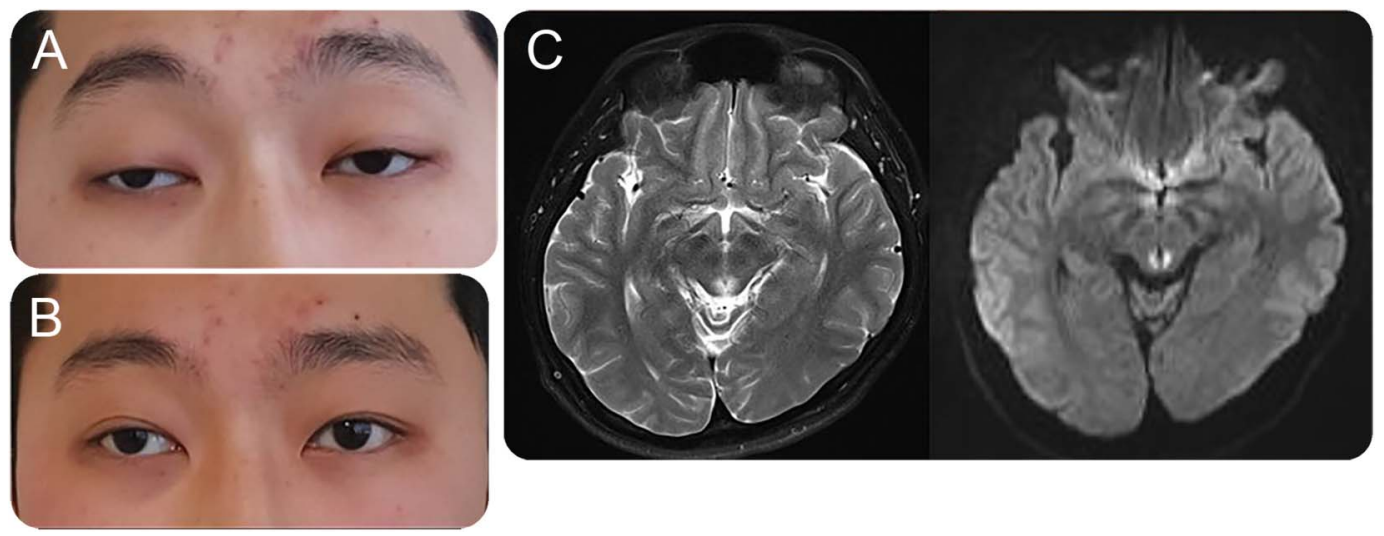

The photographs show bilateral fatigable ptosis (A), which improves at rest (B). (C) Brain MRI discloses ill-defined and symmetric hyperintensities at periaqueductal gray matter on T2- and diffusion-weighted images.

A 20-year-old man presented with bilateral fatigable ptosis for 1 month. On examination, there was bilateral incomplete ptosis, which deteriorated during upward gaze and improved at rest (figure, A and B). Tests for myasthenia gravis were all negative. Brain MRI showed symmetric hyperintensities at periaqueductal gray matter on T2- and diffusion-weighted images (figure, C). CSF lactic acid was elevated. Mitochondrial genome test demonstrated a homoplasmic T9176C mutation in the MT-APT6A gene, known as pathogenic mutation of Leigh syndrome. ${ }^{1}$ In our patient, fatigable ptosis may be ascribed to the dysfunction at centrally located synapse between the nuclear complex of the third nerve and supranuclear pathways. ${ }^{2}$

Eun Hye Oh, MD, Song-Hwa Chae, MD, Jae-Wook Cho, MD, Seung Kug Baik, MD, Seo-Young Choi, MD, Kwang-Dong Choi, MD, Jae-Hwan Choi, MD

From the Departments of Neurology (E.H.O., S.-H.C., J.-W.C., J.-H.C.) and Radiology (S.K.B.), Research Institute for Convergence of Biomedical Science and Technology, Pusan National University School of Medicine, Pusan National University Yangsan Hospital; and Department of Neurology (S.-Y.C., K.-D.C.), Pusan National University School of Medicine and Biomedical Research Institute, Pusan National University Hospital, Busan, South Korea.

Author contributions: Eun Hye Oh: study concept and design, drafting the manuscript. Song-Hwa Chae, Jae-Wook Cho, Seung Kug Baik, Seo Young Choi, Kwang-Dong Choi: analysis and interpretation of data. Jae-Hwan Choi: study concept and design, analysis and interpretation of data, study supervision.

Study funding: No targeted funding reported.

Disclosure: The authors report no disclosures relevant to the manuscript. Go to Neurology.org for full disclosures.

Correspondence to Dr.J.-H. Choi: rachelbolan@hanmail.net

1. Campos Y, Martín MA, Rubio JC, et al. Leigh syndrome associated with the T9176C mutation in the ATPase 6 gene of mitochondrial DNA. Neurology 1997;49:595-597.

2. Ragge NK, Hoyt WF. Midbrain myasthenia: fatigable ptosis, "lid twitch" sign, and ophthalmoparesis from a dorsal midbrain glioma. Neurology 1992;42:917-919. 


\title{
Neurology
}

\section{Fatigable ptosis as an initial presentation of adult-onset Leigh syndrome}

Eun Hye Oh, Song-Hwa Chae, Jae-Wook Cho, et al.

Neurology 2017;89;1754

DOI 10.1212/WNL.0000000000004528

\section{This information is current as of October 16, 2017}

\author{
Updated Information \& \\ Services \\ including high resolution figures, can be found at: \\ http://n.neurology.org/content/89/16/1754.full \\ References \\ This article cites 2 articles, 2 of which you can access for free at: \\ http://n.neurology.org/content/89/16/1754.full\#ref-list-1 \\ Subspecialty Collections \\ This article, along with others on similar topics, appears in the \\ following collection(s): \\ Eyelids \\ http://n.neurology.org/cgi/collection/eyelids \\ Mitochondrial disorders \\ http://n.neurology.org/cgi/collection/mitochondrial_disorders \\ MRI \\ http://n.neurology.org/cgi/collection/mri \\ Permissions \& Licensing \\ Information about reproducing this article in parts (figures,tables) or in \\ its entirety can be found online at: \\ http://www.neurology.org/about/about_the_journal\#permissions \\ Reprints \\ Information about ordering reprints can be found online: \\ http://n.neurology.org/subscribers/advertise
}

Neurology ${ }^{\circledR}$ is the official journal of the American Academy of Neurology. Published continuously since 1951, it is now a weekly with 48 issues per year. Copyright @ 2017 American Academy of Neurology. All rights reserved. Print ISSN: 0028-3878. Online ISSN: 1526-632X.

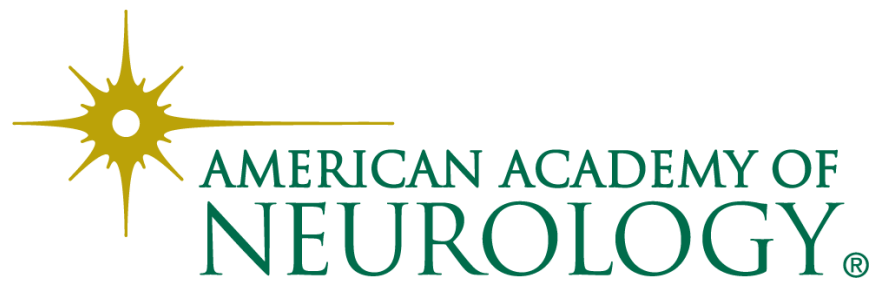

